\title{
Who's your daddy? On the identity and distribution of the paternal hybrid ancestor of the parthenogenetic gecko Lepidodactylus lugubris (Reptilia: Squamata: Gekkonidae)
}

\author{
BENJAMIN R. KARIN ${ }^{1 *}$, PAUL M. OLIVER ${ }^{2,3}$, ALEXANDER L. STUBBS ${ }^{1,13}$, UMILAELA ARIFIN ${ }^{1,4}$, DJOKO T. \\ ISKANDAR $^{5}$, EVY ARIDA ${ }^{6}$, ZHENG OONG ${ }^{1,7}$, JIMMY A. MCGUIRE ${ }^{1,14}$, FRED KRAUS $^{8}$, MATTHEW K. FUJTA ${ }^{9}$, \\ IVAN INEICH ${ }^{10}$, HIDETOSHI OTA ${ }^{11}$, STACIE A. HATHAWAY ${ }^{12,15}$ \& ROBERT N. FISHER ${ }^{12,16}$ \\ ${ }^{1}$ Museum of Vertebrate Zoology and Department of Integrative Biology, 3101 Valley Life Sciences Building, University of California, \\ Berkeley, CA 94720, USA. \\ ${ }^{2}$ Biodiversity and Geosciences Program, Queensland Museum, South Brisbane, Queensland, 4101 Australia. \\ ”"p.oliver@griffith.edu.au \\ ${ }^{3}$ Centre for Planetary Health and Food Security, Griffith University, 170 Kessels Rd, Brisbane, Queensland, 4121 Australia. \\ ${ }^{4}$ Centrum für Naturkunde-Zoologisches Museum Hamburg, Universität Hamburg, Edmund-Siemers Allee 1, 20146 Hamburg, Germany. \\ ". umilaela@gmail.com \\ ${ }^{5}$ School of Life Sciences and Technology, Institut Teknologi Bandung, Labtek XI Building, 10 Jalan Ganesa, Bandung 40132, Indonesia. \\ "“iskandar@sith.itb.ac.id \\ ${ }^{6}$ Museum Zoologicum Bogoriense (MZB), Indonesian Institute of Sciences (LIPI), Jalan Raya Bogor-Jakarta Km. 46, Cibinong 16911, \\ Indonesia. $=$ evya001@lipi.go.id \\ ${ }^{7}$ Bell Museum of Natural History and Department of Ecology, Evolution and Behavior, University of Minnesota, Saint Paul, Minnesota, \\ USA."”oong0001@umn.edu \\ ${ }^{8}$ Department of Ecology and Evolutionary Biology, University of Michigan, Ann Arbor, MI 48109, USA. \\ !"fkraus@umich.edu \\ ${ }^{9}$ Amphibian and Reptile Diversity Research Center and Department of Biology, University of Texas at Arlington, Arlington, Texas \\ 76019,USA. ”mkfujita@uta.edu \\ ${ }^{10}$ Institut de Systématique, Évolution, Biodiversité (ISYEB), Museìm national d'Histoire naturelle, Sorbonne Université, École Pra- \\ tique des Hautes Études, Université des Antilles, CNRS-CP 30, 57 rue Cuvier, CP 30, 75251 Paris, France. \\ ="ivan.ineich@mnhn.fr \\ ${ }^{11}$ Institute of Natural and Environmental Sciences, University of Hyogo, Yayoigaoka 6, Sanda, Hyogo, 669-1546, Japan. \\ ”ohta@hitohaku.jp \\ ${ }^{12}$ U.S. Geological Survey, 4165 Spruance Road, Suite 200, San Diego, CA 92101, USA. \\ 13 ”astubbs@berkeley.edu \\ ${ }^{14} \mid="$ mcguirej@berkeley.edu \\ 15 "sahathaway@usgs.gov \\ ${ }^{16}$ ”"rfisher@usgs.gov \\ *Corresponding author." benkarin@berkeley.edu
}

\begin{abstract}
The widespread parthenogenetic gecko Lepidodactylus lugubris is comprised of several clonal lineages, at least one of which has been known for some time to have originated from hybridization between its maternal ancestor, Lepidodactylus moestus, and a putatively undescribed paternal ancestor previously known only from remote islands in the Central Pacific. By integrating new genetic sequences from multiple studies on Lepidodactylus and incorporating new genetic sequences from previously sampled populations, we recovered a phylogenetic tree that shows a close genetic similarity between the generally hypothesized paternal hybrid ancestor and a recently described species from Maluku (Indonesia), Lepidodactylus pantai. Our results suggest that the paternal hybrid ancestor of at least one parthenogenetic clone of L. lugubris is conspecific with L. pantai and that the range of this species extends to Palau, the Caroline Islands, the Kei Islands, Wagabu, and potentially other small islands near New Guinea. Deeper genetic structure in the western (Palau, Maluku) versus eastern (eastern Melanesia, Micronesia, Polynesia) part of this species' range suggests that the western populations likely dispersed via natural colonization, whereas the eastern populations may be the result of human-mediated dispersal. The potential taxonomic affinities and biogeographic history should be confirmed with further morphological and genetic analyses, including research on L. woodfordi from its type locality, which would have nomenclatural priority if found to be conspecific with $L$. pantai. We recommend referring to the wide-ranging sexual species as Lepidodactylus pantai until such a comparison can be made.
\end{abstract}


Key words: anthropogenic dispersal; Lepidodactylus pantai; parthenogenesis; Scaly-toed Geckos; South Pacific; biogeography

\section{Introduction}

The gecko species Lepidodactylus lugubris (Duméril \& Bibron, 1836) is comprised of a set of clonal parthenogenetic lineages that has colonized at least scores, and likely hundreds, of islands of the Pacific Basin and has more recently been introduced across the global tropics (Kraus 2009; Nania et al. 2020). Parthenogenesis in L. lugubris was originally demonstrated by Cuellar and Kluge (1972), but it was not until 20 years later that the origin of parthenogenesis was attributed to hybridization between moderately divergent bisexual Lepidodactylus species (Volobouev et al. 1993; Radtkey et al. 1995; also see Pasteur et al. 1987). Radtkey et al. (1995) showed that some clones of L. lugubris arose via hybridization between two parental species in the Central Pacific, the maternal Lepidodactylus moestus (Peters, 1867) and a putatively undescribed paternal ancestor. They found that L. moestus had nearly identical mitochondrial cytochrome b sequences to L. lugubris, providing strong evidence that it was the maternal ancestor, and they used allozymes to determine the identity of the paternal ancestor from several candidates. After accounting for the allozyme alleles of the maternal ancestor, it became clear that a species of uncertain taxonomic affinities (and possibly undescribed) known primarily from atolls in the Tuamotu Archipelago of French Polynesia (Ineich 1999) was the paternal ancestor, as it was the only candidate they sampled that carried all the diagnostic allozyme alleles. The known ranges of Lepidodactylus moestus and the paternal species overlapped on Arno Atoll in the Marshall Islands (see Fig. 1), which Radtkey et al. suggested likely represented the location of the first hybridization that gave rise to L. lugubris. Distinct and diagnosable diploid and triploid clones of L. lugubris exist across the Pacific Basin and Southeast Asia, indicating that hybridization has occurred several times (likely in additional locations besides Arno Atoll) between these species (Ineich \& Ota 1993; Moritz et al. 1993; Volobouev et al. 1993; Radtkey et al. 1995; Ineich 1999). Backcrossing has been observed as well (Saint Girons \& Ineich 1992; Buden et al. 2014). The paternal lineage has generally been considered undescribed in subsequent literature (e.g., Zug 2013:106), and even in the most recent literature it is still referred to as "a yet undescribed Lepidodactylus species from the South Pacific" (Griffing et al. 2019) or in other similar terms (e.g., Murakami \& Hayashi 2019). Zug (2013:106) provided a more detailed morphological description of the unidentified paternal species and constrained its range to a similar area as proposed by Radtkey et al. (1995).

In 2011 and 2014, three of the authors (BK, AS, UA) discovered two island populations of a bisexual species of Lepidodactylus from beachside rocks in the Kei Islands, Indonesia (Stubbs et al. 2017; Karin et al. 2018). These populations were described as Lepidodactylus pantai Stubbs, Karin, Arifin, Iskandar, Arida, Reilly, Bloch, Kusnadi \& McGuire, 2017 on the basis of their genetic and morphological distinctiveness from all described species of Lepidodactylus (Stubbs et al. 2017). In addition, L. pantai was found in sympatry with Lepidodactylus lugubris and Lepidodactylus cf. novaeguineae Brown \& Parker, 1977 on Kur Island (Karin et al. 2018). However, the ND2 gene was used for genetic analysis, which precluded a comparison of Lepidodactylus pantai to the cytochrome $\mathrm{b}$ sequences of the paternal ancestor known from the Central Pacific identified by Radtkey et al. (furthermore, those cytochrome b sequences are not deposited on GenBank). Concurrently with the description of L. pantai, Oliver et al. (2018) investigated the evolutionary history of the Lepidodactylus radiation across Southeast Asia and the South Pacific. Oliver et al. sequenced ND2 from several of the same French Polynesian samples found by Radtkey et al. (1995) to correspond to a paternal hybrid ancestor of L. lugubris. Subsequently, for this study we have also sequenced individuals from populations of bisexual animals from Palau Islands and Palmyra Atoll. By integrating the genetic sequences used in these parallel studies and also incorporating additional island populations of $L$. pantai, we can demonstrate their close genetic similarity and shed light on the identity, distribution and some aspects of the biogeography of a paternal hybrid ancestor of L. lugubris. 


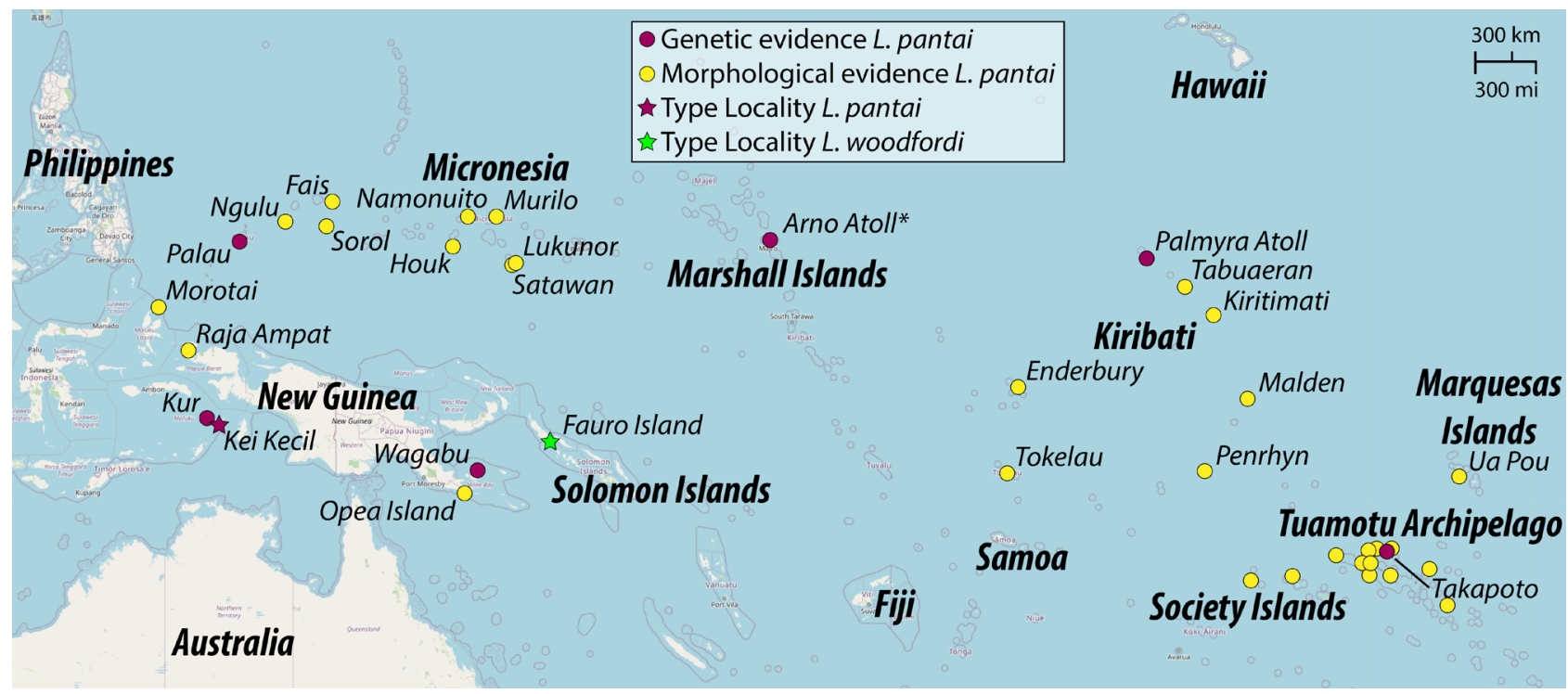

FIGURE 1. Map of the Pacific Basin displaying island populations of Lepidodactylus pantai. Red dots indicate populations with genetic sampling (*arno atoll based on cytochrome b sequences of Radtkey et al. [1995]). Yellow dots indicate populations identified by morphology either by field observations or examination of museum specimens. Stars indicate type localities of Lepidodactylus pantai (red) and Lepidodactylus woodfordi (green). Map data copyrighted OpenStreetMap contributors and available from https://www.openstreetmap.org.

\section{Materials and methods}

Museum abbreviations follow Uetz et al. (2019). We downloaded all available Lepidodactylus ND2 sequences from GenBank ( $\mathrm{n}=155,129$ of which were sequenced by Oliver et al. 2018; see Table S1). We sequenced four additional samples for the ND2 gene following the same protocols as Stubbs et al. (2017) for two samples of Lepidodactylus pantai from Kur (ALS 999, ALS 1002) and two more from Kei Kecil (ALS 718, ALS 719; see Karin et al. [2018] for details on these collections). We also sequenced an additional four samples from Palau (CAS 257444, CAS 236690-2) following the methods of Oliver et al. (2018). Finally, we assembled the ND2 gene from genomic sequence reads (Fujita et al., in prep) for L. pantai from Palmyra Atoll (CAS 247075 [RNF6366]) and an additional L. moestus (TC2076). We aligned the sequences using MAFFT v7.4.50 (Katoh et al. 2013) and trimmed the alignment ends by eye to $1038 \mathrm{bp}$ of coding sequence. We estimated the maximum-likelihood (ML) tree using IQTREE v2.1.1 (Nguyen et al. 2015), automatically selecting the best-fitting model and partitioning scheme using the $M F P+M E R G E$ option, and we calculated bootstrap proportions on the basis of 1000 ultrafast bootstrap replicates. We conducted Bayesian Inference (BI) using MrBayes v3.2.1 (Ronquist et al. 2012), with two simultaneous runs of four chains for ten million generations each, sampling every one-thousand generations until strong stationarity was confirmed by visual inspection of parameter traces and ESS values. The Bayesian analysis was partitioned based on the results of the program Partitionfinder v.21.1 (Lanfear et al. 2017), with the GTR $+\mathrm{I}+\mathrm{G}$ model applied to the first- and second-codon positions and GTR $+\mathrm{G}$ applied to third-codon positions. We built a haplotype network by extracting the Lepidodactylus pantai clade from the alignment and using the haplotype and haploNet functions in the phangorn v2.5.5 package (Schliep 2011) in R.

\section{Results}

Our recovered BI and ML topologies were identical (Fig. 2) and closely matched that of Oliver et al. (2018, Fig. S1). Samples of Lepidodactylus pantai from Kei Kecil and Kur form a clade with samples from Takapoto Atoll, Palmyra Atoll, Wagabu, and Palau Islands with $100 \%$ bootstrap support (referred to as the Lepidodactylus pantai clade hereafter). The samples from Kei Kecil show slightly higher genetic distance to the other members of the clade 


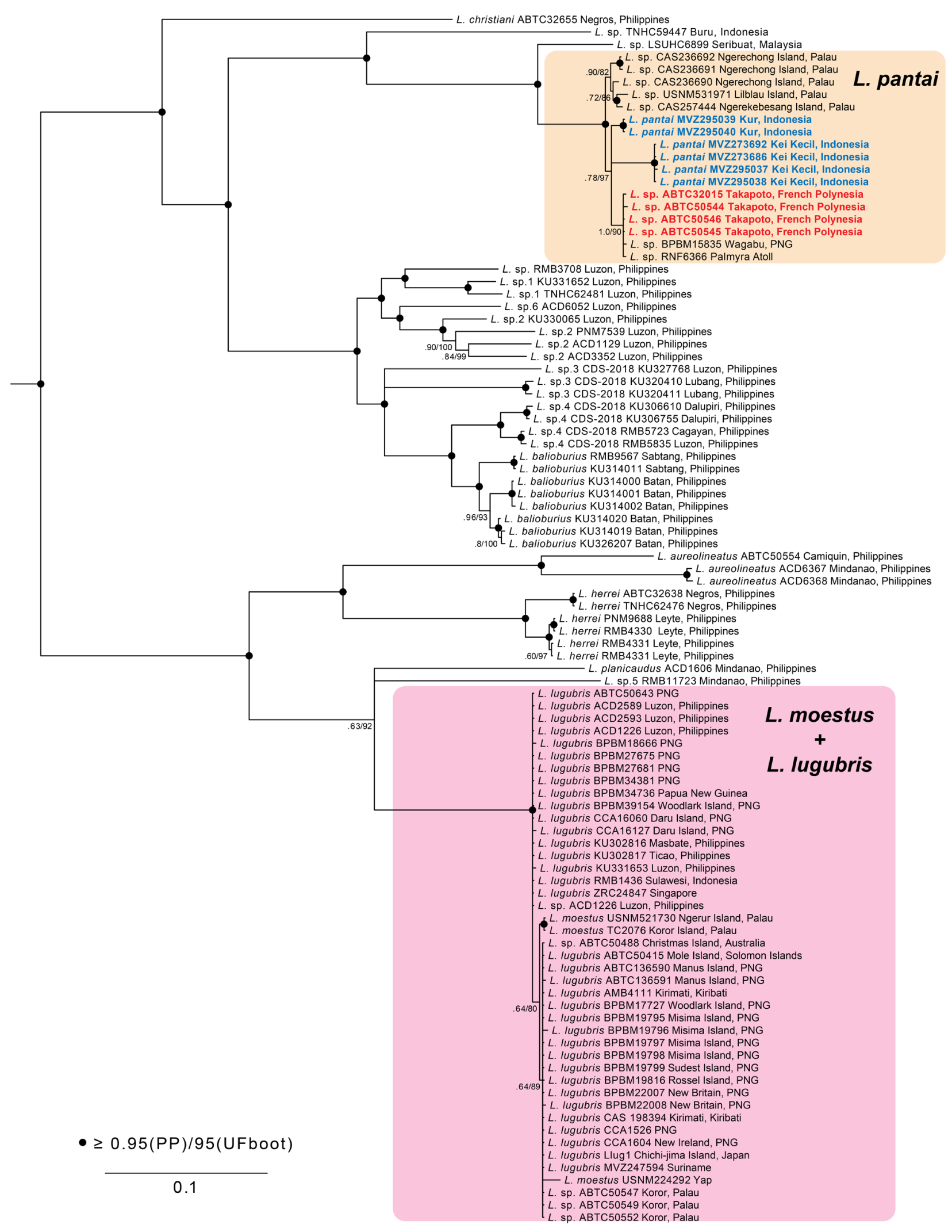

FIGURE 2. Bayesian consensus tree of the species of the Lepidodactylus lugubris Group (sensu Oliver et al. 2018) estimated using the mitochondrial ND2 gene with outgroup clades removed. Node support is indicated with posterior probability on the left and maximum-likelihood ultrafast bootstraps on the right, and solid circles on nodes supported by greater than both $95 \%$ posterior probability and $95 \%$ bootstrap score. Lepidodactylus pantai from the Kei Islands is highlighted in blue. The paternal hybrid ancestor of Lepidodactylus lugubris — as documented by Radtkey et al. (1995) — is highlighted in red. The maternal hybrid ancestor of L. lugubris is L. moestus, as determined by its mtDNA identity with L. lugubris. 
(greater than 3\%) compared to levels of divergence between the remaining island populations (usually about 1-2\%; see Table 1). We find some genetic structure amongst populations within Maluku and Palau Islands. In Maluku, we recovered up to 3.2\% raw (uncorrected patristic) distance between Kur and Kei Kecil. Between Ngerechong and Liblau islands in Palau, we recovered up to $1.3 \%$ raw distance. Conversely, samples from Wagabu near New Guinea were most similar to those in French Polynesia (7000 km east) and Palmyra Atoll $(5500 \mathrm{~km})$, at only $0.1-0.2 \%$ raw distance (only 1-2 mutations in ND2). The L. pantai clade was recovered with $100 \%$ support as sister to a candidate species of Lepidodactylus from Seribuat island off the coast of Peninsular Malaysia (8.4-9.5\% raw distance). Together, L. pantai and the Seribuat sample were recovered with 100\% support as sister to a different candidate species of Lepidodactylus from Buru island, in Maluku, Indonesia (16.1-18.5\% raw distance). The haplotype network (Fig. 3) mirrors the maximum-likelihood tree, with western populations tending to show deeper genetic diversity, while samples scattered across eastern New Guinea to French Polynesia show very shallow genetic diversity (at most one to two base pairs different).

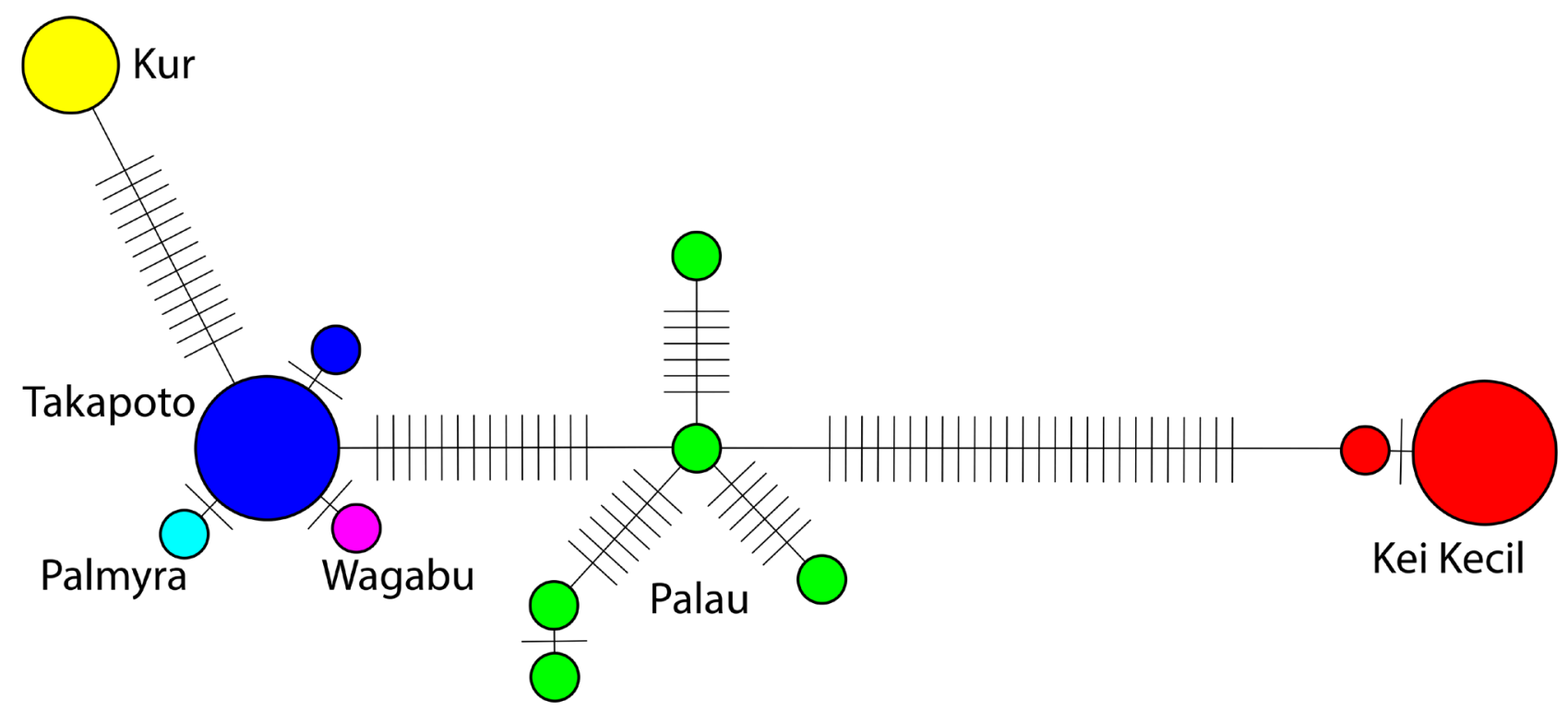

FIGURE 3. Haplotype network for the Lepidodactylus pantai clade estimated for the mitochondrial ND2 gene. Circle sizes correspond to the number of individuals sharing a given haplotype and hash marks designate the number of nucleotide differences between haplotypes. Colors correspond to labeled locations.

TABLE 1. Ranges of raw pairwise genetic distances for ND2 within and between island populations of Lepidodactylus pantai.

\begin{tabular}{|c|c|c|c|c|c|c|}
\hline & Kei & Kur & Takapoto & Palmyra & Wagabu & Palau \\
\hline Kei $(n=4)$ & $0.1-0.3 \%$ & - & - & - & - & - \\
\hline $\operatorname{Kur}(n=2)$ & $3.0-3.2 \%$ & $0 \%$ & - & - & - & - \\
\hline Takapoto* $(n=4)$ & $3.2-3.3 \%$ & $1.3-1.4 \%$ & $0-0.1 \%$ & - & - & - \\
\hline Palmyra $(\mathrm{n}=1)$ & $3.3-3.4 \%$ & $1.4 \%$ & $0.1-0.2 \%$ & NA & - & - \\
\hline Wagabu $(\mathrm{n}=1)$ & $3.5 \%$ & $1.6 \%$ & $0.1-0.2 \%$ & $0.2 \%$ & NA & - \\
\hline Palau $(n=6)$ & $3.3-3.9 \%$ & $1.6-2.3 \%$ & $1.6-2.3 \%$ & $1.7-2.1 \%$ & $1.8-2.6 \%$ & $0.1-1.3 \%$ \\
\hline
\end{tabular}

*Samples included in Radtkey et al. 1995 and identified as a paternal ancestor to L. lugubris based on allozyme data.

\section{Discussion}

The high degree of genetic similarity between Lepidodactylus pantai from its type locality in eastern Indonesia and other bisexual Lepidodactylus samples spanning the entire South Pacific makes a strong case that the entire clade should be recognized as a single species. Furthermore, given that the Takapoto Atoll samples we included in this study are the same as those studied by Radtkey et al. (1995) and which also carry the allozyme alleles found in the L. lugubris unisexual-bisexual complex sensu Ineich (1988), it follows that this species may be attributable to 
Lepidodactylus pantai. These patterns suggest that this paternal ancestor of L. lugubris is not limited to the island groups between French Polynesia (Takapoto Atoll) and the Marshall Islands (Arno Atoll), as proposed by Radtkey et al. (1995), but also occurs across the Central Pacific, the Western Pacific in Palau, on several small islands near New Guinea, and likely on many more islands as well (see also Buden and Taborosi 2016). For example, FK has observed L. pantai from Opea island (Fig. 4B), a small island just off the coast of southeastern New Guinea (see Fig. 1). Pending morphological and genomic analyses to confirm this conclusion, we assign all these bisexual populations to Lepidodactylus pantai.

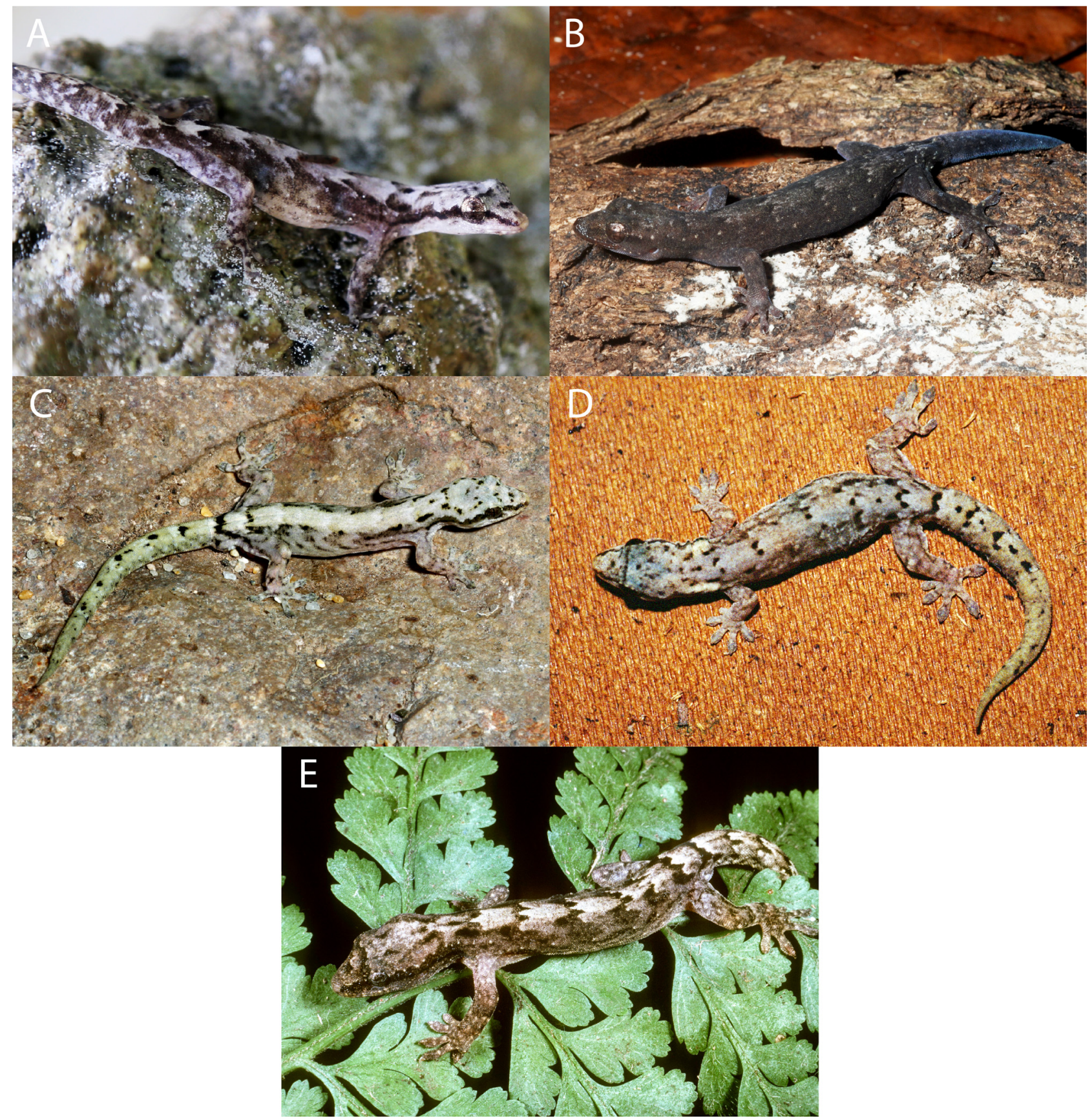

FIGURE 4. Photos in life comparing putative members of Lepidodactylus pantai or Lepidodactylus woodfordi. (A) Lepidodactylus pantai from the type locality, Kei Kecil, Indonesia (photo by Luke M. Bloch). (B) Lepidodactylus cf. pantai from Opea Island, Papua New Guinea (photo by Fred Kraus). The dark coloration is the night-time coloration, whereas during the day (and in preservative) they show similar coloration as the other images. (C) Lepidodactylus pantai from Palmyra Atoll (photo by Robert Fisher). (D) Lepidodactylus pantai from Rangiroa Atoll (Tuamotu Archipelago) (photo by Ivan Ineich). (E) Lepidodactylus cf. woodfordi from Alu Island, Solomon Islands, adjacent to Fauro Island, the type locality of $L$. woodfordi (photo by Michael $\mathrm{McCoy}$ ). Further comparison is needed to assess if $L$. woodfordi may be conspecific with $L$. pantai and would therefore have priority. 
The greater genetic structuring observed among populations of Lepidodactylus pantai in the western versus eastern portions of the range allows for a comparison of the likelihood of natural versus human-mediated dispersal. Palau Islands and the Kei Islands both show substantial within-population genetic structure, suggesting that they are likely to be naturally occurring populations that have existed on the islands for some time, likely for more than one million years (Stubbs et al. 2017). In addition, the related lineages on Buru and Seribuat are evidence that this clade of Lepidodactylus has a long history of diversification and persistence on or near the Sunda Shelf and Wallacea. Furthermore, the reduced genetic distance between samples from Kur Island and populations outside of Indonesia — and the resulting closer haplotype grouping as compared to Kei Kecil samples (Fig. 3) -is evidence that isolated populations have existed on and around these islands for quite some time.

On the other hand, the limited genetic structure recovered between Wagabu, Palmyra Atoll, and Takapoto Atoll raises the likelihood that the species was introduced to the remote South Pacific by humans. Our results are similar to patterns suspected for Lepidodactylus moestus on the basis of eastward reduction in the degree of intrapopulation color-polymorphism and variability in lepidoses (Ota et al. 1995; Ota, unpublished data). This pattern is also observed in South Pacific Emoia and Lipinia skinks that hold increased genetic structure in the western versus eastern Pacific Basin, supporting human-mediated dispersal to more eastern islands (Austin 1999; Klein et al. 2016). Conversely, skinks of the genus Cryptoblepharus (Blom et al. 2019) and the Emoia atrocostata complex (Richmond et al. 2020), as well as geckos of the Gehyra oceanica complex (Fisher 1997; Tonione et al. 2016), the Gehyra vorax group (Oliver et al. 2016), and the Lepidodactylus manni group (Oliver et al. 2018) appear to have colonized much of the South Pacific by natural means, as evidenced by their genetic structure and levels of heterozygosity. More thorough genetic sampling from intervening island populations of $L$. pantai is warranted to investigate natural versus human-mediated dispersal.

If Lepidodactylus pantai is capable of dispersing to some of the most remote islands in the Pacific Basin, why then has it not been observed on the largest and most-visited islands in the region, such as New Guinea, Fiji, Samoa, Tonga, Niue, Nauru, or the largest Society Islands despite its expansive encompassing distribution? We speculate that this is due to L. pantai being uniquely adapted to fringe, species-poor habitats, and that it is unable to establish populations on larger islands (Oliver et al. 2018). Throughout its range, L. pantai is also almost exclusively found on beachside limestone rocks, debris, and vegetation on small islands and atolls (Stubbs et al. 2017; Zug 2013:106). These habitats are likely to have reduced inter-specific competition and/or predation. Additionally, they occur in a high trophic position in these simplified food-webs (Briggs et al. 2012). On larger islands and in inland forest habitats with more complex and species-rich lizard communities, L. pantai may be precluded from establishing due to competition and/or predation. For example, in the Seribuat archipelago the sister lineage of L. pantai is restricted to beachside habitats on islands where large gekkonids are present (Grismer et al. 2011). Even on small islands, Ineich (1999) provided evidence of ecological displacement and temporal replacement and/or marginalization of $L$. pantai by L. lugubris in French Polynesia, further suggesting the former species is uniquely sensitive to competition with recently introduced unisexual clones of $L$. lugubris. The role of biotic interactions in shaping distribution patterns will be an intriguing aspect of further research on island Lepidodactylus, as previously noted by Oliver $e t$ al. (2018).

The distribution of the entire Lepidodactylus pantai clade suggests that there are additional islands beyond small Arno Atoll on which L. pantai and L. moestus coinhabit. For example, L. moestus and L. pantai are both known from several of the small islands in the Caroline Islands and Palau Islands; therefore, these represent alternative potential locations of hybrid origin for additional L. lugubris clones (Buden \& Taborosi 2016). Given the number of unique parthenogenetic lineages of L. lugubris (Ineich 1988; Ineich \& Ota 1992; Yamashiro et al. 2000), it is likely that hybridization of different bisexual parental ancestors gave rise to numerous diploid and triploid clones and some have subsequently been introduced elsewhere (Radtkey et al. 1995; Ineich 1999; Ineich et al. 2015), whereas others remain restricted to small original islets (Murakami \& Hayashi 2019; Yamashiro et al. 2000). In addition, backcrossing and/or potential hybridization with other species is likely to have occurred to produce multiple diploid and triploid clones (Saint Girons \& Ineich 1992; Buden et al. 2014; Trifonov et al. 2015). A more precise location of different hybridization events forming unique clones of $L$. lugubris may be possible to infer by using genomic sequencing of multiple island populations of $L$. pantai as well as the many morphologically and/or genetically identified clones of the L. lugubris unisexual-bisexual complex. This is assuming there is enough nuclear-sequence variation to distinguish each population, which seems likely given the amount of mitochondrial diversity in the clade (see Table 1). Based on previous allozyme and Class I major histocompatibility complex studies that show very limited 
genetic diversity (Pasteur et al. 1987; Hanley et al. 1995, Radtkey et al. 1996), genomic assessments of diversity for different island populations could also help to illuminate the extent to which L. pantai and L. lugubris have been anthropogenically dispersed across the numerous remote islands across the Central Pacific it inhabits.

A thorough morphological and molecular comparison of the known populations of Lepidodactylus pantai across the South Pacific is warranted to expand on our results here. To confirm the appropriate name for this widespread clade, we must ascertain that no other Lepidodactylus in the Pacific Basin could possibly refer to this clade. Of particular relevance is Lepidodactylus woodfordi Boulenger, 1887, described from small Fauro Island in the Solomon Islands. Many South Pacific island populations (that may now be referrable to L. pantai) have been assigned in recent years to $L$. woodfordi, despite its sparse description, highlighting the persistent taxonomic confusion that has occurred in this clade as a whole. Brown and Parker (1977) found L. woodfordi to be similar to L. lugubris, and if the type refers to a member of the clade we recovered here, then it would have nomenclatural priority over L. pantai. Due to logistical constraints during the COVID-19 pandemic, we were unable to examine the holotype of $L$. woodfordi for this manuscript, and the photographic material for $L$. cf. woodfordi from Alu Island (McCoy 2021) in the Solomon Islands near the type locality (see Fig. 4) is insufficient to solve this taxonomic issue here. The presence of a cylindrical tail without lateral serrations was a key character used to originally diagnose Kei Island L. pantai from L. woodfordi (Stubbs et al. 2017); however, these and other characters may prove to be variable across its now-expanded range and need to be compared to $L$. woodfordi. We hope to undertake this more-thorough morphological investigation in the future, but in the present study we limit ourselves to simply observing the close relationship between $L$. woodfordi and populations of what we assign to L. pantai across Maluku and a vast expanse of the Pacific Basin. By clearly recognizing that one very widespread bisexual parental species is involved, we can now move forward to investigating the incredible story of hybridization, parthenogenesis, and dispersal that has occurred in these gecko lineages.

\section{Acknowledgements}

We thank Kementerian Riset, Teknologi, dan Pendidikan Tinggi Republik Indonesia for facilitating permitting and collaboration between UC Berkeley and our Indonesian collaborators. We also thank Gilang Ramadan and Luke Bloch for support and help in the field in the Kei Islands. We thank Carol Spencer and the Museum of Vertebrate Zoology for critical help importing specimens. Mike McCoy kindly provided the image 4E. Funding for this work was provided by an Australian Research Council Grant to Paul Oliver. We thank George Zug and another anonymous reviewer for their time and comments on the manuscript. Any use of trade, firm, or product names is for descriptive purposes only and does not imply endorsement by the U.S. Government.

\section{References}

Austin, C. (1999) Lizards took express train to Polynesia. Nature, 397, 113-114. https://doi.org/10.1038/16365

Boulenger, G.A. (1887) Catalogue of the Lizards in the British Museum (Natural History). Second Edition. Volume III. Lacertidae, Gerrhosauridae, Scincidae, Anelytropidae, Dibamidae, Chamaeleontidae. British Museum (Natural History), London, xii +575 pp., XL pls.

Blom, M.P.K., Matzke, N.J., Bragg, J.G., Arida, E., Austin, C.C., Backlin, A., Carretero, M.A., Fisher, R.N., Glaw, F., Hathaway, S. A., Iskandar, D.T., McGuire, J.A., Karin, B.R., Reilly, S.B., Rittmeyer, E.N., Rocha, S., Sanchez, M., Stubbs, A.L., Vences, M. \& Moritz, C. (2019) Habitat preference modulates trans-oceanic dispersal in a terrestrial vertebrate. Proceedings of the Royal Society B Biological Sciences, 286, 20182575. https://doi.org/10.1098/rspb.2018.2575

Briggs, A.A., Young, H.S., McCauley, D.J., Hathaway, S.A., Dirzo, R. \& Fisher, R.N. (2012) Effects of spatial subsidies and habitat structure on the foraging ecology and size of geckos. PLOS ONE, 7, e41364 https://doi.org/10.1371/journal.pone.0041364

Brown, W. \& Parker, F. (1977) Lizards of the genus Lepidodactylus (Gekkonidae) from the Indo-Australian Archipelago and the islands of the Pacific, with descriptions of new species. Proceedings of the California Academy of Science, 41, $253-265$.

Buden, D.W., Cianchini, C., Taborosi, D., Fisher, R.N., Bauer, A.M. \& Ineich, I. (2014) Photographic evidence of interspecies mating in geckos of the Lepidodactylus lugubris unisexual-bisexual complex (Squamata: Gekkonidae). Phylomedusa, 13, $133-136$. https://doi.org/10.11606/issn.2316-9079.v13i2p133-136 
Buden, D.W. \& Taborosi, D. (2016) Reptiles of the Federated States of Micronesia. Island Research \& Education Initiative, Palikir, Pohnpei, 359 pp.

Cuellar, O. \& Kluge, A.G. (1972) Natural parthenogenesis in the gekkonid lizard Lepidodactylus lugubris. Journal of Genetics, $61,14-26$. https://doi.org/10.1007/BF02984098

Duméril, A.M.C. \& Bibron, G. (1836) Erpétologie Générale ou Histoire Naturelle Compléte des Reptiles. Vol. 3. Libr. Encyclopédique Roret, Paris, 528 pp.

Fisher, R.N. (1997) Disperal and evolution of the Pacific basin gekkonid lizards Gehyra oceanica and Gehyra mutilata. Evolution, 51, 3, 906-921. https://doi.org/10.1111/j.1558-5646.1997.tb03672.x

Griffing, A.H., Sanger, T.J., Daza, J.D., Nielsen, S.V., Pinto, B.J., Stanley, E.L. \& Gamble, T. (2019) Embryonic development of a parthenogenetic vertebrate, the mourning gecko (Lepidodactylus lugubris). Developmental Dynamics, 248, 1070-1090. https://doi.org/10.1002/dvdy.72

Grismer, L.L. (2011) Field Guide to the Amphibians and Reptiles of the Seribuat Archipelago, Peninsular Malaysia. Edition Chimaira, Frankfurt am Main, 258 pp.

Hanley, K.A., Fisher, R.N. \& Case T.J. (1995) Lower mite infestations in an asexual gecko compared with its sexual ancestors. Evolution, 49, 418-426. https://doi.org/10.1111/j.1558-5646.1995.tb02274.x

Ineich, I. (1988). Mise en évidence d'un complexe unisexué-bisexué chez le gecko Lepidodactylus lugubris (Sauria, Lacertilia) en Polynésie française. Comptes Rendus de l'Académie des Sciences, Paris, 307, 271-277.

Ineich, I. (1999) Spatio-temporal analysis of the unisexual-bisexual Lepidodactylus lugubris complex (Reptilia, Gekkonidae). In: Ota, H. (Ed.) Tropical Island Herpetofauna: Origin, Current Diversity and Conservation. Elsevier, Developments in Animal and Veterinary Sciences, pp. 199-228.

Ineich, I. (2015) New data about the triploid clone C of the unisexual-bisexual Lepidodactylus lugubris (Dumeìril \& Bibron, 1836) complex (Gekkonidae). Herpetology Notes, 8, 165-168.

Ineich, I. \& Ota, H. (1992) Additional Remarks on the Unisexual-Bisexual Complex of the Gecko, Lepidodactylus lugubris, in Takapoto Atoll, French Polynesia. Bulletin of the College of Science, University of the Ryukyus, 53, 31-39.

Ineich, I. \& Ota, H. (1993) Morphological variation and distribution of the unisexual-bisexual complex of the gecko, Lepidodactylus lugubris, in French Polynesia and Easter Island. Bulletin of the College of Science, University of the Ryukyus, 56, 113-120.

Karin, B.R., Stubbs, A.L., Arifin, U., Bloch, L.M., Ramadhan, G., Iskandar, D.T., Arida, E., Reilly, S.B., Kusnadi, A. \& McGuire, J.A. (2018) The herpetofauna of the Kei Islands (Maluku, Indonesia): Comprehensive report on new and historical collections, biogeographic patterns, conservation concerns, and an annotated checklist of species from Kei Kecil, Kei Besar, Tam, and Kur. Raffles Bulletin of Zoology, 66, 704-738.

Katoh, K. \& Standley, D.M. (2013). MAFFT multiple sequence alignment software version 7: Improvements in performance and usability. Molecular Biology and Evolution, 30, 772-780. https://doi.org/10.1093/molbev/mst010

Kraus, F. (2009) Alien reptiles and amphibians: A scientific compendium and analysis. Springer, Dordrecht, 563 pp. https://doi.org/10.1007/978-1-4020-8946-6

Lanfear, R., Frandsen, P.B., Wright, A.M., Senfeld, T. \& Calcott, B. (2017) PartitionFinder 2: New methods for selecting partitioned models of evolution for molecular and morphological phylogenetic analyses. Molecular Biology and Evolution, 34 (3), $772-773$. https://doi.org/10.1093/molbev/msw260

Klein, E.R., Harris, R.B., Fisher, R.N. \& Reeder, T.W. (2016) Biogeographical history and coalescent species delimitation of Pacific island skinks (Squamata: Scincidae: Emoia cyanura species group). Journal of Biogeography, 43, $1917-1929$. https://doi.org/10.1111/jbi.12772

McCoy, M. (2021) A Field Guide to the Reptiles of the Solomon Islands. Michael McCoy, Kuranda, $147 \mathrm{pp}$.

Moritz, C., Case, T.J., Bolger, D.T. \& Donnellan, S. (1993) Genetic diversity and the history of Pacific island house geckos (Hemidactylus and Lepidodactylus). Biological Journal of the Linnean Society, 48, 113-133. https://doi.org/10.1111/j.1095-8312.1993.tb00882.x

Murakami, Y. \& Hayashi, F. (2019) Molecular discrimination and phylogeographic patterns of clones of the parthenogenetic gecko Lepidodactylus lugubris in the Japanese Archipelago. Population Ecology, 61, 315- 324. https://doi.org/10.1002/1438-390X.1030

Nania, D., Flecks, M. \& Rödder, D. (2020) Continuous expansion of the geographic range linked to realized niche expansion in the invasive Mourning gecko Lepidodactylus lugubris (Duméril \& Bibron, 1836). PLoS ONE, 15, 7, e0235060. https://doi.org/10.1371/journal.pone.0235060

Nguyen, L.T., Schmidt, H.A., Von Haeseler, A. \& Minh, B.Q. (2015) IQ-TREE: A fast and effective stochastic algorithm for estimating maximum-likelihood phylogenies. Molecular Biology and Evolution, 32 (1), 268-274. https://doi.org/10.1093/molbev/msu300

Oliver, P.M., Brown, R.M., Kraus, F., Rittmeyer, E., Travers, S.L. \& Siler, C.D. (2018) Lizards of the lost arcs: Mid-Cenozoic diversification, persistence and ecological marginalization in the West Pacific. Proceedings of the Royal Society B, 285, 20171760. https://doi.org/10.1098/rspb.2017.1760 
Oliver, P.M., Clegg, J.R., Fisher, R.N., Richards, S.J., Taylor, P.T. \& Jocque, M.M.T. (2016) A new biogeographically disjunct giant gecko (Gehyra: Gekkonidae: Reptilia) from the East Melanesian Islands. Zootaxa, 4208 (1), 61-76. http://doi.org/10.11646/zootaxa.4208.1.3

Ota, H., Fisher, R.N., Ineich, I. \& Case, T.J. (1995) Geckos of the genus Lepidodactylus (Squamata: Reptilia) in Micronesia: Description of a new species and reevaluation of the status of Gecko moestus Peters, 1867. Copeia, 1995, 1, $183-195$. https://doi.org/10.2307/1446813

Pasteur, G., Agnèse, J.-F., Blanc, C. P. \& Pasteur, N. (1987) Polyclony and low relative heterozygosity in a widespread unisexual vertebrate, Lepidodactylus lugubris (Sauria). Genetica, 75, 71-79. https://doi.org/10.1007/BF00056034

Peters, W.C.H. (1867) Herpetologische Notizen. Monatsbericht der Königlich Preussischen Akademie der Wissenschaften zu Berlin, January 1867, 13-37.

Radtkey, R.R., Donnellan, S.C., Fisher, R.N., Moritz, C., Hanley, K.A. \& Case, T.J. (1995) When species collide: the origin and spread of an asexual species of gecko. Proceedings of the Royal Society London B, 259, 145-152. https://doi.org/10.1098/rspb.1995.0022

Radtkey, R.R., Becker, B., Miller, R.D., Riblet, R. \& Case T.J. (1996) Variation and evolution of Class I Mhe in sexual and parthenogenetic geckos. Proceedings of the Royal Society B, 263, 1023-1032. https://doi.org/10.1098/rspb.1996.0151

Richmond, J.Q., Ota, H., Grismer, L.L. \& Fisher, R.N. (2020) Influence of niche breadth and position on the historical biogeography of seafaring scincid lizards. Biological Journal of the Linnean Society, 132, 1, 74-92. https://doi.org/10.1093/biolinnean/blaa172

Ronquist, F., Teslenko, M., Mark, P., Ayres, D.L., Darling, A., Hona, S., Larget, B., Liu, L., Suchard, M.A. \& Huelsenbeck, J.P. (2012) MrBayes 3.2: efficient Bayesian phylogenetic inference and model choice across a large model space. Systematic Biology, 61, 539-542. https://doi.org/10.1093/sysbio/sys029

Saint Girons, H. \& Ineich, I. (1992) Histology of the reproductive tract of hybrids between gonochoristic males and parthenogenetic females of Lepidodactylus lugubris in French Polynesia (Reptilia, Gekkonidae). Journal of Morphology, 212, 55-64. https://doi.org/10.1002/jmor.1052120106

Schliep, K.P. (2011) phangorn: phylogenetic analysis in R. Bioinformatics, 27, 592-593. https://doi.org/10.1093/bioinformatics/btq706

Stubbs, A.L., Karin, B.R., Arifin, U., Iskandar, D.T., Arida, E., Reilly, S.B., Bloch, L.M., Kusnadi, A. \& McGuire, J.A. (2017) A new species of Lepidodactylus (Reptilia: Squamata: Gekkonidae) from the Kei Islands, Maluku, Indonesia. Zootaxa, $4350,1,91-105$. https://doi.org/10.11646/zootaxa.4350.1.5

Tonione, M.A., Fisher, R.N., Zhu, C. \& Moritz, C. (2016) Deep divergence and structure in the Tropical Oceanic Pacific: A multilocus phylogeography of a widespread gekkonid lizard (Squamata: Gekkonidae: Gehyra oceanica). Journal of Biogeography, 43, 268-278. https://doi.org/10.1111/jbi.12645

Trifonov, V.A., Paoletti, A., Caputo, B.V., Kalinina, T., O’Brien, P.C.M., Ferguson-Smith, M.A. \& Giovannotti, M. (2015) Comparative chromosome painting and NOR distribution suggest a complex hybrid origin of triploid Lepidodactylus lugubris (Gekkonidae). PLoS ONE, 10 (7), e0132380. https://doi.org/10.1371/journal.pone.0132380

Uetz, P., Cherikh, S., Shea, G., Ineich, I., Campbell, P.D., Doronin, I. V., Rosado, J., Wynn, A., Tighe, K.A., McDiarmid, R., Lee, J.L., Köhler, G., Ellis, R., Doughty, P., Raxworthy, C. J., Scheinberg, L., Resetar, A., Sabaj, M., Schneider, G., Franzen, M., Glaw, F., Böhme, W., Schweiger, S., Gemel, R., Couper, P., Amey, A., Dondorp, E., Ofer, G., Meiri, S. \& Wallach, V. (2019) A global catalog of primary reptile type specimens. Zootaxa, 4695 (5), 438-450. https://doi.org/10.11646/zootaxa.4695.5.2

Volobouev, V., Pasteur, G., Ineich, I. \& Dutrillaux, B. (1993) Chromosomal evidence for a hybrid origin of diploid parthenogenetic females from the unisexual-bisexual Lepidodactylus lugubris complex (Reptilia, Gekkonidae). Cytogenetic Cell Genetics, 63, 194-199. https://doi.org/10.1159/000133533

Yamashiro, S., Toda, M. \& Ota, H. (2000) Clonal composition of the parthenogenetic gecko, Lepidodactylus lugubris, at the northernmost extremity of its range. Zoological Science, 17, 1013-1020. https://doi.org/10.2108/zsj.17.1013

Zug, G.R. (2013) Reptiles and amphibians of the Pacific Islands: A comprehensive guide. University of California Press, Oakland, California, $306 \mathrm{pp}$. https://doi.org/10.1525/9780520955400 
TABLE S1. List of samples used for phylogenetic analysis and corresponding Genbank accession numbers. Lepidodactylus pantai and newly sequenced specimens are displayed at the top of the table. Note that the Fig. 2 tree was cropped so not all specimens below are displayed.

\begin{tabular}{|c|c|c|c|}
\hline Species & Location & Voucher & Accession \\
\hline Lepidodactylus pantai & Kur, Indonesia & MVZ:Herp:295039 & MZ189431 \\
\hline Lepidodactylus pantai & Kur, Indonesia & MVZ:Herp:295040 & MZ189432 \\
\hline Lepidodactylus pantai & Kei Kecil, Indonesia & MVZ:Herp:295037 & MZ189429 \\
\hline Lepidodactylus pantai & Kei Kecil, Indonesia & MVZ:Herp:295038 & MZ189430 \\
\hline Lepidodactylus pantai & Ngerekebesang Island, Palau & CAS 257444 & MZ189426 \\
\hline Lepidodactylus pantai & Ngerechong Island, Palau & CAS 236690 & MZ189425 \\
\hline Lepidodactylus pantai & Ngerechong Island, Palau & CAS 236691 & MZ189424 \\
\hline Lepidodactylus pantai & Ngerechong Island, Palau & CAS 236692 & MZ189423 \\
\hline Lepidodactylus pantai & Palmyra Atoll, USA & CAS 247075 & MZ189428 \\
\hline Lepidodactylus pantai & Kei Kecil, Indonesia & MVZ:Herp:273692 & KY794934 \\
\hline Lepidodactylus pantai & Kei Kecil, Indonesia & MZB.Lace.14064 & KY794935 \\
\hline Lepidodactylus pantai & Takapoto, French Polynesia & ABTC32015 & MG780811 \\
\hline Lepidodactylus pantai & Takapoto, French Polynesia & ABTC50544 & MG780812 \\
\hline Lepidodactylus pantai & Takapoto, French Polynesia & ABTC50545 & MG780813 \\
\hline Lepidodactylus pantai & Takapoto, French Polynesia & ABTC50546 & MG780814 \\
\hline Lepidodactylus pantai & Wagabu Isand, Papua New Guinea & BPBM15835 & MG780816 \\
\hline Lepidodactylus pantai & Lilblau Island, Palau & USNM531971 & MG780820 \\
\hline Lepidodactylus moestus & Koror Island, Palau & TC2076 (RNF431) & MZ189427 \\
\hline Lepidodactylus aignanus & & ВРВМ17229 & MG780808 \\
\hline Lepidodactylus aureolineatus & & ABTC50554 & MG780702 \\
\hline Lepidodactylus aureolineatus & & ACD6367 & MG780700 \\
\hline Lepidodactylus aureolineatus & & ACD6368 & MG780701 \\
\hline Lepidodactylus balioburius & & KU314000 & MG780703 \\
\hline Lepidodactylus balioburius & & KU314001 & MG780704 \\
\hline Lepidodactylus balioburius & & KU314002 & MG780705 \\
\hline Lepidodactylus balioburius & & KU314019 & MG780706 \\
\hline Lepidodactylus balioburius & & KU314020 & MG780707 \\
\hline Lepidodactylus balioburius & & KU326207 & MG780708 \\
\hline Lepidodactylus balioburius & & RMB9567 & MG780709 \\
\hline Lepidodactylus browni & & ENR0183 & MG780710 \\
\hline Lepidodactylus christiani & & ABTC32655 & MG780711 \\
\hline Lepidodactylus euaensis & & ABTC50699 & MG780715 \\
\hline Lepidodactylus euaensis & & USNM 322126 & JX515611 \\
\hline Lepidodactylus flaviocularis & & KU341207 & MG780716 \\
\hline Lepidodactylus guppyi & & ABTC50473 & MG780717 \\
\hline Lepidodactylus guppyi & & MNHN 2004.0094 & JX515612 \\
\hline Lepidodactylus herrei & & ABTC32638 & MG780718 \\
\hline Lepidodactylus herrei & & PNM9688 & MG780720 \\
\hline Lepidodactylus herrei & & RMB4331 & MG780721 \\
\hline Lepidodactylus herrei & & RMB 4330 & JQ173539 \\
\hline Lepidodactylus herrei & & RMB 4331 & JQ173540 \\
\hline Lepidodactylus herrei & & TNHC62476 & MG780719 \\
\hline
\end{tabular}


TABLE S1. (Continued)

\begin{tabular}{|c|c|c|c|}
\hline Species & Location & Voucher & Accession \\
\hline Lepidodactylus kwasnickae & & ВРВМ39152 & MG780824 \\
\hline Lepidodactylus kwasnickae & & ВРВМ39879 & MG780825 \\
\hline Lepidodactylus kwasnickae & & ВРВМ39880 & MG780826 \\
\hline Lepidodactylus listeri & & ABTC6880 & MG780724 \\
\hline Lepidodactylus listeri & & ABTC6881 & MG780725 \\
\hline Lepidodactylus listeri & & ABTC14644 & MG780722 \\
\hline Lepidodactylus listeri & & & GQ257746 \\
\hline Lepidodactylus listeri & & ABTC50488 & MG780723 \\
\hline Lepidodactylus lugubris & & ABTC50415 & MG780728 \\
\hline Lepidodactylus lugubris & & ABTC50643 & MG780729 \\
\hline Lepidodactylus lugubris & & ABTC 136590 & MG780726 \\
\hline Lepidodactylus lugubris & & ABTC136591 & MG780727 \\
\hline Lepidodactylus lugubris & & ACD2589 & MG780730 \\
\hline Lepidodactylus lugubris & & ACD2593 & MG780731 \\
\hline Lepidodactylus lugubris & & ACD:1226 & KF219759 \\
\hline Lepidodactylus lugubris & & AMB4111 & MG780732 \\
\hline Lepidodactylus lugubris & & BPBM17727 & MG780733 \\
\hline Lepidodactylus lugubris & & BPBM18666 & MG780734 \\
\hline Lepidodactylus lugubris & & BPBM19795 & MG780735 \\
\hline Lepidodactylus lugubris & & ВРВМ19796 & MG780736 \\
\hline Lepidodactylus lugubris & & ВРВМ19797 & MG780737 \\
\hline Lepidodactylus lugubris & & ВРВМ19798 & MG780738 \\
\hline Lepidodactylus lugubris & & BPBM19799 & MG780739 \\
\hline Lepidodactylus lugubris & & BPBM19816 & MG780740 \\
\hline Lepidodactylus lugubris & & ВРВМ22007 & MG780741 \\
\hline Lepidodactylus lugubris & & BPBM22008 & MG780742 \\
\hline Lepidodactylus lugubris & & BPBM27675 & MG780743 \\
\hline Lepidodactylus lugubris & & ВРВМ27681 & MG780744 \\
\hline Lepidodactylus lugubris & & ВРВМ34381 & MG780745 \\
\hline Lepidodactylus lugubris & & ВРВМ34736 & MG780746 \\
\hline Lepidodactylus lugubris & & ВРВМ39154 & MG780747 \\
\hline Lepidodactylus lugubris & & CAS 198394 & JX515613 \\
\hline Lepidodactylus lugubris & & CCA1526 & MG780748 \\
\hline Lepidodactylus lugubris & & CCA1604 & MG780749 \\
\hline Lepidodactylus lugubris & & CCA16060 & MG780750 \\
\hline Lepidodactylus lugubris & & CCA16127 & MG780751 \\
\hline Lepidodactylus lugubris & & KU302816 & MG780752 \\
\hline Lepidodactylus lugubris & & KU302817 & MG780753 \\
\hline Lepidodactylus lugubris & & KU314011 & MG780754 \\
\hline Lepidodactylus lugubris & & KU331653 & MG780755 \\
\hline Lepidodactylus lugubris & & & NC_025782 \\
\hline Lepidodactylus lugubris & & MVZ 247594 & JX515614 \\
\hline Lepidodactylus lugubris & & RMB1436 & MG780756 \\
\hline
\end{tabular}


TABLE S1. (Continued)

\begin{tabular}{|c|c|c|}
\hline Location & Voucher & Accession \\
\hline Lepidodactylus lugubris & ZRC 24847 & JN393944 \\
\hline Lepidodactylus lugubris & ABTC50547 & MG780815 \\
\hline Lepidodactylus lugubris & ABTC50549 & MG780793 \\
\hline Lepidodactylus lugubris & ABTC50552 & MG780794 \\
\hline Lepidodactylus magnus & ABTC50585 & MG780757 \\
\hline Lepidodactylus magnus & ABTC50586 & MG780758 \\
\hline Lepidodactylus magnus & ABTC50587 & MG780759 \\
\hline Lepidodactylus magnus & ABTC50589 & MG780760 \\
\hline Lepidodactylus magnus & ABTC50584 & MG780800 \\
\hline Lepidodactylus manni & ABTC 32753 & MG780761 \\
\hline Lepidodactylus manni & АBTC32754 & MG780762 \\
\hline Lepidodactylus manni & USNM 322638 & JX515615 \\
\hline Lepidodactylus mitchelli & BPBM15843 & MG780796 \\
\hline Lepidodactylus mitchelli & BPBM15845 & MG780797 \\
\hline Lepidodactylus moestus & USNM 521730 & JN019079 \\
\hline Lepidodactylus moestus & USNM-FS 224292 & JX515616 \\
\hline Lepidodactylus novaeguineae & BPBM:15842 & JX041378 \\
\hline Lepidodactylus novaeguineae & ВРВM 15842 & JX515617 \\
\hline Lepidodactylus orientalis & ВРВМ 19794 & JN019080 \\
\hline Lepidodactylus orientalis & CCA3833 & MG780764 \\
\hline Lepidodactylus orientalis & CCA15287 & MG780763 \\
\hline Lepidodactylus orientalis & CCA15300 & MG780765 \\
\hline Lepidodactylus orientalis & ENR0175 & MG780766 \\
\hline Lepidodactylus orientalis & ENR0179 & MG780767 \\
\hline Lepidodactylus orientalis & ENR0180 & MG780772 \\
\hline Lepidodactylus orientalis & ENR0181 & MG780768 \\
\hline Lepidodactylus orientalis & ENR0182 & MG780769 \\
\hline Lepidodactylus orientalis & ENR0227 & MG780770 \\
\hline Lepidodactylus orientalis & ENR0348 & MG780771 \\
\hline Lepidodactylus planicaudus & ACD1606 & MG780773 \\
\hline Lepidodactylus pollostos & ABTC90234 & MG780817 \\
\hline Lepidodactylus pumilus & LSU97472 & MG780774 \\
\hline Lepidodactylus pumilus & LSU97473 & MG780775 \\
\hline Lepidodactylus ranauensis & ID7174 & MG780776 \\
\hline Lepidodactylus sacrolineatus & ABTC48538 & MG780798 \\
\hline Lepidodactylus sacrolineatus & ABTC48583 & MG780799 \\
\hline Lepidodactylus sacrolineatus & ВРВМ34737 & MG780801 \\
\hline Lepidodactylus sp. & ABTC104666 & MG780809 \\
\hline Lepidodactylus sp. & ABTC114706 & MG780810 \\
\hline Lepidodactylus sp. & ВРВМ25943 & MG780805 \\
\hline Lepidodactylus sp. & ВРВМ31738 & MG780806 \\
\hline Lepidodactylus sp. & BPBM40272 & MG780807 \\
\hline Lepidodactylus sp. & BPBM42860 & MG780819 \\
\hline
\end{tabular}

......continued on the next page 
TABLE S1. (Continued)

\begin{tabular}{|c|c|c|}
\hline Location & Voucher & Accession \\
\hline Lepidodactylus sp. & ENR0753 & MG780803 \\
\hline Lepidodactylus sp. & ENR1125 & MG780804 \\
\hline Lepidodactylus sp. & LSU95824 & MG780795 \\
\hline Lepidodactylus sp. & LSU95849 & MG780821 \\
\hline Lepidodactylus sp. & LSU97474 & MG780822 \\
\hline Lepidodactylus sp. & LSU97475 & MG780823 \\
\hline Lepidodactylus sp. & LSUHC6899 & MG780818 \\
\hline Lepidodactylus sp. & MZB.Lace.14062 & KY794932 \\
\hline Lepidodactylus sp. & MZB.Lace.14063 & KY794933 \\
\hline Lepidodactylus sp. & RMB3708 & MG780777 \\
\hline Lepidodactylus sp. & TNHC59447 & MG780802 \\
\hline Lepidodactylus sp. 1 CDS-2018 & KU331652 & MG780778 \\
\hline Lepidodactylus sp. 1 CDS-2018 & TNHC62481 & MG780779 \\
\hline Lepidodactylus sp. 2 CDS-2018 & ACD1129 & MG780780 \\
\hline Lepidodactylus sp. 2 CDS-2018 & ACD3352 & MG780781 \\
\hline Lepidodactylus sp. 2 CDS-2018 & KU330065 & MG780782 \\
\hline Lepidodactylus sp. 2 CDS-2018 & PNM7539 & MG780783 \\
\hline Lepidodactylus sp. 3 CDS-2018 & KU320410 & MG780784 \\
\hline Lepidodactylus sp. 3 CDS-2018 & KU320411 & MG780785 \\
\hline Lepidodactylus sp. 3 CDS-2018 & KU327768 & MG780786 \\
\hline Lepidodactylus sp. 4 CDS-2018 & KU306610 & MG780787 \\
\hline Lepidodactylus sp. 4 CDS-2018 & KU306755 & MG780788 \\
\hline Lepidodactylus sp. 4 CDS-2018 & RMB5723 & MG780789 \\
\hline Lepidodactylus sp. 4 CDS-2018 & RMB5835 & MG780790 \\
\hline Lepidodactylus sp. 5 CDS-2018 & RMB11723 & MG780791 \\
\hline Lepidodactylus sp. 6 CDS-2018 & ACD6052 & MG780792 \\
\hline Lepidodactylus sp. CDS-2018a & ENR0706 & MG780712 \\
\hline Lepidodactylus sp. CDS-2018a & ENR0719 & MG780713 \\
\hline Lepidodactylus sp. CDS-2018a & ENR0752 & MG780714 \\
\hline Lepidodactylus sp. MPH-2012 & ACD 1226 & JX515618 \\
\hline Lepidodactylus sp. MPH-2012 & USNM 531971 & JX515619 \\
\hline Lepidodactylus sp. MPH-2012 & USNM 533293 & JX515620 \\
\hline Lepidodactylus vanuatuensis & АВТC 32720 & MG780827 \\
\hline Lepidodactylus vanuatuensis & ABTC50700 & MG780828 \\
\hline Lepidodactylus vanuatuensis & MNHN 2008.0052 & JX515622 \\
\hline Lepidodactylus vanuatuensis & USNM 323265 & JX515621 \\
\hline
\end{tabular}

